\title{
Carbonate Rocks of
}

\section{Cambrian and Ordovician Age}

Northampton and Bucks

Counties, Eastern Pennsylvania

and Warren and Hunterdon

Counties, Western New Jersey

By AVERY ALA DRAKE, JR.

CONTRIBUTIONS TO STRATIGRAPHY

G EOLOG I C A L S URVEY B ULL ET I N $1194-$ L 


\section{UNITED STATES DEPARTMENT OF THE INTERIOR \\ STEWART L. UDALL, Secretary}

\section{GEOLOGICAL SURVEY}

Thomas B. Nolan, Director

The U.S. Geological Survey Library catalog card for this publication appears after page L7.

UNITED STATES GOVERNMENT PRINTING OFFICE, WASHINGTON : 1965

For sale by the Superintendent of Documents, U.S. Government Printing Office Washington, D.C. 20402 - Price 10 cents (paper cover) 


\section{CONTENTS}



CONTRIBUTIONS TO STRATIGRAPHY

\title{
CARBONATE ROCKS OF CAMBRIAN AND ORDOVICIAN AGE, NORTHAMPTON AND BUCKS COUNTIES, EASTERN PENNSYLVANIA, AND WARREN AND HUNTERDON COUNTIES, WESTERN NEW JERSEY
}

\author{
By Avery Ala Drake, Jr.
}

\section{ABSTRACT}

Detailed mapping near the Delaware River has shown that the carbonate rocks lying between the Hardyston Quartzite of Early Cambrian age and the Martinsburg Shale of Middle and Late Ordovician age can be divided into four cartographic units. These units include the Leithsville Formation, Allentown Dolomite, the Beekmantown Group-consisting of the Rickenbach Dolomite and Epler Formation-and the Jacksonburg Limestone. These units have been mapped in an area of more than 400 square miles and can be recognized in southern New York.

\section{INTRODUCTION}

The stratigraphy of the carbonate rocks of the Lehigh and Delaware Valleys has long been problematical because of lithologic similarity, lack of paleontologic data, and structural complexity. The rocks younger than the Hardyston Quartzite of Early Cambrian age and older than the high-calcium limestone of Middle Ordovician age have been particularly difficult to separate and even more difficult to map. In New Jersey, Kummel (1901) adopted the term Kittatinny Limestone for this sequence, and to the present day, the New Jersey Geological Survey follows his usage. Wherry (1909) first suggested a division of these rocks in Pennsylvania and proposed the names Leithsville, Allentown and Coplay, but did not test their mappability. The Leithsville included the thin- to thick-bedded dolomite and dolomitic limestone and interbedded sericitic shale that overlies the Hardyston Quartzite. The name Allentown Limestone was proposed for the stratigraphically younger oolitic dolomite of Late Cambrian age that characteristically weathers light and dark gray. The Coplay included limestone and dolomite of Early Ordovician age. B. L. Miller, D. M. Frazer, and R. L. Miller (1939) substituted Tomstown (a formational name in southeastern Pennsylvania) for Leithsville, and 
Beekmantown for Coplay. Howell, Roberts, and Willard (1950) again revised the stratigraphic nomenclature in this area, reinstating the Leithsville Formation and dividing the Allentown Limestone into Limeport and Allentown (sensu stricto) Formations. Recent detailed mapping by my associates and me in eight $71 / 2$-minute quadrangles in this area (fig. 1) has shown that five formations are consistently mappable (table 1). Drake, McLaughlin, and Davis (1961) recognized the Leithsville Formation as used both by Wherry (1909) and by Howell, Roberts, and Willard (1950), and the formation was so mapped throughout the study area. In our work, however, Howell, Roberts, and Willard's division of the Allentown is rejected, as their formations are unmappable and Wherry's (1909) original usage is reinstated. The lithologic term, however, is changed from limestone to dolomite. The Beekmantown (Coplay of Wherry) is herein recognized as a group consisting of the Rickenbach Dolomite and the Epler Formation.

The reference section for the Allentown Dolomite and the Beekmantown Group in the mapped area is exposed in a series of abandoned quarries and natural outcrops along the Delaware River, the Pennsylvania Railroad, and the Carpentersville Road about one-half mile south of Carpentersville, N.J. This section begins just north of Pohatcong Creek in the Allentown Dolomite. So far as is known, this is the only section in the mapped area that includes this stratigraphic interval.

TABLE 1.-Stratigraphic nomenclature used by previous workers and in this report

\begin{tabular}{|c|c|c|c|c|}
\hline Wherry (1909) & B. L. Miller and others & $\begin{array}{c}\text { Howell, Roberts, and } \\
\text { Willard (1950) }\end{array}$ & & This report \\
\hline Nazareth Formation & $\begin{array}{l}\text { Upper Jacksonburg Lime- } \\
\text { stone (cement rock) }\end{array}$ & & \multirow{2}{*}{ 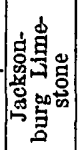 } & Cement rock facies \\
\hline Nisky Formation & $\begin{array}{l}\text { Lower Jacksonburg Lime- } \\
\text { stone (cement lime- } \\
\text { stone) }\end{array}$ & & & $\begin{array}{c}\text { Cement limestone } \\
\text { facies }\end{array}$ \\
\hline \multirow[b]{2}{*}{ Coplay Limestone } & \multirow[b]{2}{*}{$\begin{array}{l}\text { Beekmantown Forma- } \\
\text { tion }\end{array}$} & \multirow[b]{2}{*}{$\begin{array}{l}\text { Beekmantown For- } \\
\text { mation }\end{array}$} & \multirow{2}{*}{ 音 } & Epler Formation \\
\hline & & & & $\begin{array}{l}\text { Rickenbach Dolo- } \\
\text { mite }\end{array}$ \\
\hline \multirow{2}{*}{ Allentown Limestone } & \multirow{2}{*}{ Allentown Formation } & Allentown Formation & \multirow{2}{*}{\multicolumn{2}{|c|}{ Allentown Dolomite }} \\
\hline & & Limeport Formation & & \\
\hline \multirow[t]{2}{*}{ Leithsville Limestone } & Tomstown Formation & Leithsville Formation & \multicolumn{2}{|c|}{ Leithsville Formation } \\
\hline & Hardyston Formation & Elardyston Formation & \multicolumn{2}{|c|}{ Hardyston Quartzite } \\
\hline
\end{tabular}




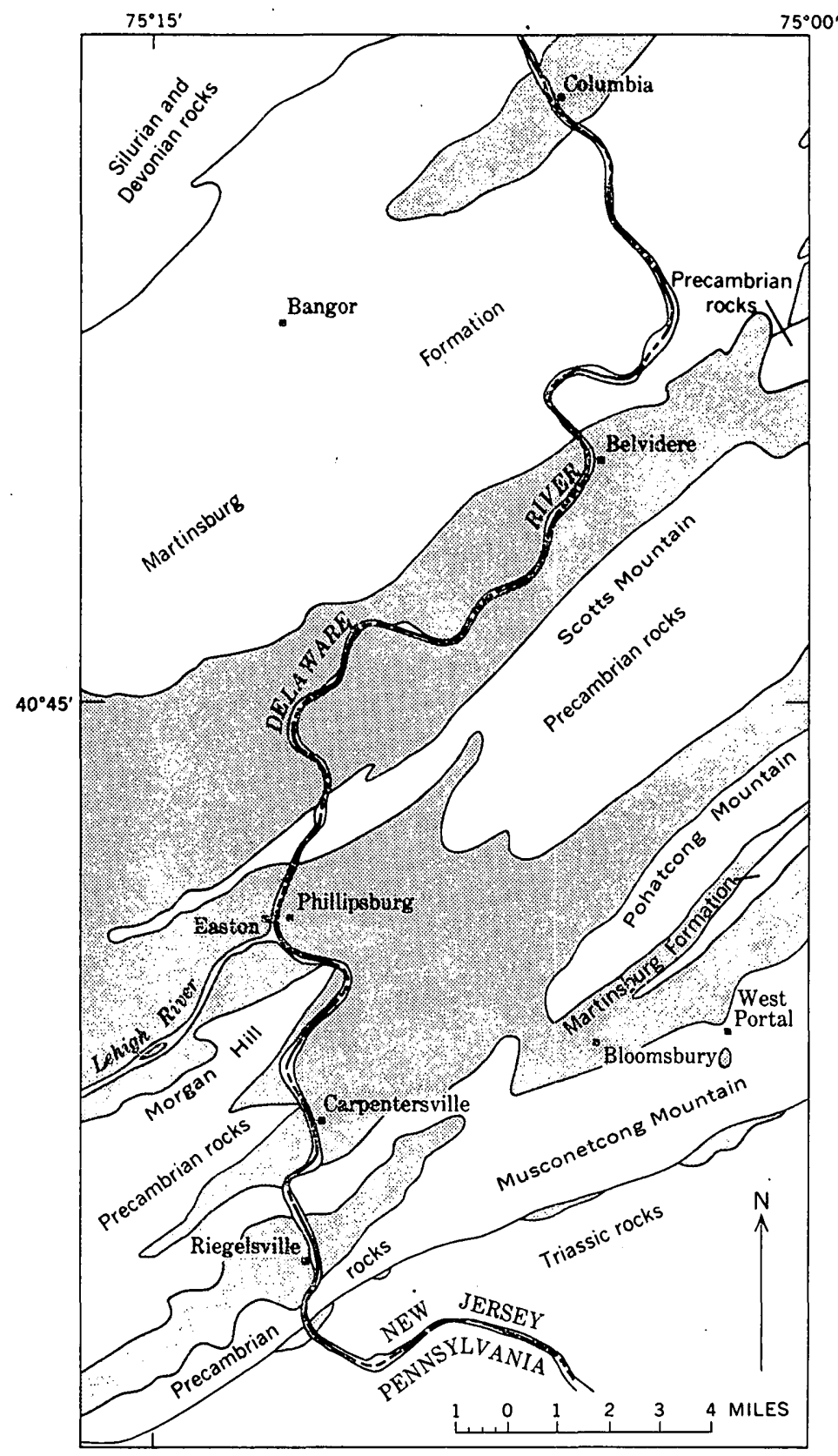

Figorn 1.-Geology and distribution of carbonate rocks (shaded) of Cambrian and Ordovician age near the Delaware River in eastern Pennsglvania and western New Jersey. 


\section{ALLENTOWN DOLOMTTE}

The Allentown Dolomite is a light-medium gray or light-olive gray to dark-medium gray, fine- to medium-grained rock that weathers characteristically light and dark gray in alternating beds. Bedding thickness alternates rhythmically from poorly laminated, massive beds averaging 3 feet in thickness, to platy or shaly beds less than an inch in thickness. Beds of oolite, orthoquartzite, dolarenite, and desiccation dolorudite are common. Colonies of several varieties of stromatolites are characteristic of the whole formation but are more abundant in the lower and middle parts. Alternations in color, bedding, and other megascopic features and in the texture as revealed by microscopic study all show the cyclic nature of the Allentown Dolomite. A succession of six different types of dolomite is recognized by Zadnik (1960) as forming an ideal cycle. The cycle from bottom to top, is as follows: Textureless dololutite, dolarenite, oolitic dolarenite, dolorudite, cryptozoan dolomite, and desiccation dolorudite. Individual cycles range from 5 to about 30 feet in thickness. Toward the top of the formation, microfacies of cryptozoan dolomite and desiccation dolorudite tend to disappear, and lenses and irregular beds of dark-gray chert appear. The formation is about 1,700 feet thick in this area; 1,610 feet was measured at Carpentersville, N.J., where the basal part is covered. The lower contact is transitional with the underlying Leithsville Formation and in measured sections is placed at the base of the lowest Allentown cycle. In mapping, the contact is placed at the lowest recognized stromatolite colony or oolite bed. The upper contact is transitional with the Rickenbach Dolomite and in measured sections is placed at the top of the highest Allentown cycle. In mapping, the contact is placed below the lowest bed of medium-coarse to coarsecrystalline thin-bedded calcareous dolomite or above the highest stromatolite colony, oolite, desiccation dolorudite, or orthoquartzite bed. Weller (1899) dated the Allentown Dolomite as Late Cambrian. Howell, Roberts, and Willard (1950) attempted a subdivision of the Allentown into Limeport and Allentown (sensu stricto) Formations primarily upon faunal evidence largely gained from outside this area. This evidence suggested to them that both early and late Upper Cambrian strata are present in the Allentown and that middle Upper Cambrian rocks are absent. No lithologic features have been recognized, however, that allow the systematic mapping of their formations in this area.

\section{BEEKMANTOWN GROUP}

Detailed mapping shows that strata previously assigned to the Beekmantown Formation consist of two mappable lithologies, a dolomite unit, herein called the Rickenbach Dolomite, and an interbedded 
dolomite and limestone unit, herein called the Epler Formation. The establishment of a Beekmantown Group in this area follows the usage of Hobson (1957) and others now (1964) working in east-central Pennsylvania. Hobson's (1957) Beekmantown Group in Berks County, Pa., consists of the Stonehenge, Rickenbach, Epler, and Ontelaunee Formations. In the mapped area, only the Rickenbach and Epler can be recognized, as the Stonehenge apparently pinches out between the areas. A pronounced unconformity at the top of the Beekmantown Group in this area may explain the absence of the Ontelaunee Formation.

\section{RICKENBACH DOLOMITE}

The lower unit of the Beekmantown Group in this area includes about 635 feet of various types of dolomite. The lower part of the formation consists of thin- to thick-bedded light-medium gray to medium-dark gray medium-fine to coarsely crystalline dolomite. The coarsely crystalline beds are calcareous, and both bedded and nodular cherts are common. This part of the formation is characterized by a patchy ruditic texture, well shown on weathered surfaces but barely visible in freshly broken rock. The phenoclasts consist of tiny crystals of dolomite and, more rarely, of calcite and are enclosed in a matrix of more coarsely crystalline dolomite. Dolomite boulder conglomerate and sedimentary breccia are also present. The upper part of the formation is generally similar to the lower but is more finely crystalline. Many beds have a "dirty" appearance because of an abundance of silt and sand grains. The Rickenbach Dolomite grades into the overlying Epler Formation. The contact is placed at the base of the lowest limestone bed both in measured sections and in mapping.

\section{EPLER FORMATION}

A heterogeneous assemblage of about 800 feet of interbedded dolomite and limestone above the Rickenbach Dolomite is assigned to the Epler Formation. The limestones are light gray to medium gray, are very fine crystalline to cryptocrystalline, and occur in beds that average less than 1 foot in thickness. Many beds are so finely laminated that they resemble shale.

The dolomite beds are largely fine crystalline to cryptocrystalline, more rarely medium crystalline, medium light gray to dark medium gray, and commonly laminated or mottled. Nodular or bedded chert is common throughout the formation, but a zone very rich in chert is near the base. This zone serves as a useful criteria in mapping the Rickenbach-Epler contact. In this area the Epler is disconformably overlain by the Jacksonburg Limestone. A different Epler lithology is present at each place where the upper contact has been observed. 


\section{JACKSONBURG LIMESTONE}

High-calcium limestone of Middle Ordovician age has been quarried for the manufacture of portland cement in this area. These rocks, called the Nisky and Nazareth Formations by Wherry (1909) and referred to collectively as the Jacksonburg Limestone (R. L. Miller, 1937), consist of a lower cement limestone facies of very pure granular limestone and an upper cement-rock facies of argillaceous very fine grained limestone. In this report, the Jacksonburg Limestone is used in that sense.

The lower cement limestone facies is medium to dark gray fine to coarse grained largely well bedded calcarenite and crystalline limestone. In the area studied, the cement limestone facies has a basal unit of calcirudite that contains pebbles ranging from 0.5 to $50 \mathrm{~cm}$ in diameter. These clasts are gray fine-grained dolomite or dark-gray chert suggesting a probable Beekmantown source. The matrix of the calcirudite is typical calcarenite of the cement limestone facies. According to W. Cullen Sherwood (written commun., 1961), the basal calcirudite is absent west of Nazareth, $\mathrm{Pa}$.

The upper cement-rock facies of the Jacksonburg Limestone is a dark-gray to almost black fine-grained argillaceous limestone. Presumably, it is thin bedded, although in all exposures slaty cleavage is by far the dominant planar element. Deformation has been so intense in the area mapped that fossils are only rarely found; strongly smeared bryozoa seem most common.

Data are not available on which to base a valid estimate of the thickness of the Jacksonburg throughout the area. In the Alpha Portland Cement Co. quarries at Martins Creek, Pa., in the Bangor quadrangle, about 765 feet of cement limestone and more than 300 feet (could be more than $600 \mathrm{ft}$ ) of cement rock are present (John A. Ames, written commun., 1961). It appears, however, that the cement limestone facies more commonly is 250 to 400 feet thick. The Jacksonburg Limestone is conformably overlain by slates of the Martinsburg Shale; in the area mapped the contact appears to be gradational.

\section{REFERENCES CITED}

Drake, A. A. Jr., McLaughlin, D. B., and Davis, R. E., 1961, Geology of the Frenchtown quadrangle, New Jersey-Pennsylvania : U.S. Geol. Survey Geol. Quad. Map GQ-133.

Hobson, J. P., 1957, Lower Ordovician (Beekmantown) succession in Berks County, Pennsylvania: Am. Assoc. Petroleum Geologists Bull., v. 41, p. 2710-2722.

Howell, B. F., Roberts, Henry, and Willard, Bradford, 1950, Subdivision and dating of the Cambrian of eastern Pennsylvania: Geol. Soc. America Bull., v. 61, p. 1355-1368. 
Kummel, H. B., 1901, Annual report of the State Geologist: New Jersey Geol. Survey, $231 \mathrm{p}$.

Miller, R. L., 1937, Stratigraphy of the Jacksonburg Limestone: Geol. Soc. America Bull., v. 48, p. 1687-1718.

Miller, B. L., Fraser, D. M., and Miller, R. L., 1939, Northampton County, Pennsylvania : Pennsylvania Geol. Survey Bull. C-48, ser. 4, $496 \mathrm{p}$.

Weller, Stuart, 1899, Description of Cambrian trilobites from New Jersey: New Jersey Geol. Survey Ann. Rept. p. 47-52.

Wherry, E. T., 1909, The early Paleozoics of the Lehigh Valley District, Pennsylvania: Science, new ser., v. 30, p. 416.

Zadnik, V. E., 1960, Petrography of the Upper Cambrian dolomites of Warren County, New Jersey : U.S. Geol. Survey open-file report, $96 \mathrm{p}$. 
The U.S. Geological Survey Library has cataloged this publication as follows:

Drake, Avery Ala, 1927-

Carbonate rocks of Cambrian and Ordovician age, Northampton and Bucks Counties, eastern Pennsylvania, and Warren and Hunterdon Counties, western New Jersey. [Washington, U.S. Govt. Print. Off., 1965]

iii, 7 p. map, table. 24 cm. (U.S. Geological Survey. Bulletin 1194-L)

Contributions to stratigraphy.

Bibliography : p. 6-7.

(Continued on next card)

Drake, Avery Ala, 1927- Carbonate rocks of Cambrian and Ordovician age, Northampton and Bucks Counties, eastern Pennsylvania, and Warren and Hunterdon Counties western New Jersey. [1965] (Card 2)

1. Carbonates. 2. Geology, Stratigraphic-Paleozoic. 3. GeologyPennsylvania. 4. Geology-New Jersey. 5. Geology-Nomenclature. I. Title : Carbonate rocks of Cambrian and Ordovician age. (Series) 